\title{
PENERAPAN METODE DISCOVERY LEARNING UNTUK MENINGKATKAN MOTIVASI BELAJAR SISWA KELAS $X$ MATA PELAJARAN BIOLOGI MATERI JAMUR DI SMA NEGERI 3 SIMPANG HILIR KABUPATEN KAYONG UTARA TAHUN PELAJARAN 2015/2016
}

\section{Mugi Utomo ${ }^{1}$ \\ SMA Negeri 3 Simpang Hilir Kabupaten Kayong Utara Email: mugiutomo@yahoo.com}

\begin{abstract}
Abstrak: Penelitian ini bertujuan untuk memperbaiki proses pelaksanaan pembelajaran dan meningkatkan motivasi belajar siswa dengan menerapkan metode pembelajaran Discovery Learning pada pokok bahasan Jamur pada siswa kelas X. Bentuk penelitian yang digunakan adalah Penelitian Tindakan Kelas, dilaksanakan di kelas X SMAN 3 Simpang Hilir Tahun Ajaran 2015/2016 dengan jumlah siswa sebanyak 31 orang. Instrument yang digunakan dalam penelitian ini adalah berupa lembar observasi untuk mengukur motivasi belajar siswa dan soal tes pilihan ganda berjumlah 20 butir untuk mengukur hasil belajar. Dari hasil analis didapatkan bahwa prestasi belajar siswa mengalami peningkatan dari siklus I sampai siklus II yaitu, siklus I $(51,16)$ dan siklus II $(71,23)$. Ketuntasan klasikal siklus I (22,58\%) dan siklus II (70,97\%). Dengan demikian dapat disimpulkan bahwa penerapan metode discovery learning dapat meningkatkan motivasi belajar siswa.
\end{abstract}

Kata Kunci: pembelajaran biologi, metode discovery learning, motivasi belajar

\begin{abstract}
The aim of this research was to improve the process of learning and student motivation by implementing discovery learning on Fungi subject. This study conducted through a Classroom Action Research. This research was done in the class X SMAN 3 Simpang Hilir in Academic Year 2015/2016. They consisted of 31 students. The instruments was used in this research was an observation sheet and multiple choice questions that consisted 20 questions. The students averages on first cycle were 51.16, and on second cycle were 71.23. it revealed that $22,58 \%$ on first cycle and $70,97 \%$ on second cycle. Based
\end{abstract}

\footnotetext{
${ }^{1}$ Mugi Utomo adalah SMA Negeri 3 Simpang Hilir Kabupaten Kayong Utara
} 
on the mentioned results above, it can be concluded that improving students motivation through discovery learning on Fungi subject of class X SMAN 3 Simpang Hilir was successful to be implemented.

Keywords: learning outcome, discovery learning, student motivation

\section{PENDAHULUAN}

Perubahan pada sistem pendidikan di Indonesia sekarang ini telah mengalami banyak perubahan dan perkembangan. Perubahan-perubahan itu terjadi karena telah dilakukan berbagai usaha pembaharuan dalam bidang pendidikan dari tingkat dasar sampai perguruan tinggi dan pengaruh pendidikan semakin mengalami perkembangan dan kemajuan.

Guru mengemban tugas yang berat untuk tercapainya tujuan pendidikan nasional yaitu meningkatkan kualitas manusia Indonesia, manusia seutuhnya yang beriman dan bertakwa terhadap Tuhan Yang Maha Esa, berbudi pekerti luhur, berkepribadian, berdisiplin, bekerja keras, tangguh, bertanggung jawab, mandiri, cerdas dan terampil serta sehat jasmani dan rohani, juga harus mampu menumbuhkan dan memperdalam rasa cinta terhadap tanah air, mempertebal semangat kebangsaan dan rasa kesetiakawanan sosial. Sejalan dengan pembaharuan pendidikan nasional akan mampu mewujudkan manusia-manusia pembangunan dan rnembangun dirinya sendiri serta bertanggung jawab atas pembangunan bangsa (Depdikbud, 1999).

Untuk itu diperlukan suatu upaya dalam rangka meningkatkan mutu pendidikan dan pengajaran salah satunya adalah dengan memilih strategi atau cara dalam menyampaikan materi pelajaran agar diperoleh peningkatan prestasi belajar siswa khususnya pelajaran Biologi pada materi Jamur. Misalnya dengan membimbing siswa untuk bersama-sama terlibat aktif dalam proses pembelajaran dan mampu membantu siswa berkembang sesuai dengan taraf intelektualnya akan lebih menguatkan pemahaman siswa terhadap konsep-konsep yang diajarkan. Pemahaman ini memerlukan minat dan motivasi. Tanpa adanya minat menandakan bahwa siswa tidak mempunyai motivasi untuk belajar. Untuk itu, guru harus memberikan suntikan dalam bentuk motivasi sehingga dengan bantuan itu anak didik dapat keluar dari kesulitan belajar. Sehingga nilai rata-rata mata pelajaran Biologi materi Jamur yang diharapkan oleh guru adalah tuntas KKM yaitu 67,00.

Berdasarkan pengalaman penulis di lapangan, kegagalan dalam belajar rata-rata dihadapi oleh sejumlah siswa yang tidak memiliki dorongan belajar. Sehingga nilai rata-rata mata pelajaran Biologi sangat rendah yaitu mencapai 40,00. Hal ini disebabkan karena guru dalam proses belajar mengajar hanya menggunakan metode ceramah, tanpa menggunakan alat peraga, dan materi pelajaran tidak disampaikan secara kronologis. 
Untuk itu dibutuhkan suatu kegiatan yang dilakukan oleh guru dengan upaya membangkitkan motivasi belajar siswa, misalnya dengan membimbing siswa untuk terlibat langsung dalam kegiatan yang melibatkan siswa serta guru yang berperan sebagai pembimbing untuk menemukan konsep Biologi pada materi Jamur.

Motivasi tidak hanya menjadikan siswa terlibat dalam kegiatan akademik, motivasi juga penting dalam menentukan seberapa jauh siswa akan belajar dari suatu kegiatan pembelajaran atau seberapa jauh menyerap informasi yang disajikan kepada mereka. Siswa yang termotivasi untuk belajar sesuatu akan menggunakan proses kognitif yang lebih tinggi dalam mempelajari materi itu, sehingga siswa itu akan meyerap dan mengendapkan materi itu dengan lebih baik. Tugas penting guru adalah merencanakan bagaimana guru mendukung motivasi siswa (Nur, 2001 : 3). Untuk itu sebagai seorang guru disamping menguasai materi, juga diharapkan dapat menetapkan dan melaksanakan penyajian materi yang sesuai kemampuan dan kesiapan anak, sehingga menghasilkan penguasaan materi yang optimal bagi siswa.

Berdasarkan uraian tersebut di atas penulis mencoba menerapkan salah satu metode pembelajaran, yaitu metode pembelajaran Discovery Learning untuk mengungkapkan apakah dengan model tersebut dapat meningkatkan minat dan motivasi belajar Biologi, sehingga bisa didapatkan prestasi belajar yang baik. Penulis memilih metode pembelajaran ini mengkondisikan siswa untuk terbiasa menemukan, mencari, mendikusikan sesuatu yang berkaitan dengan pengajaran. (Siadari, 2001: 4). Dalam metode pembelajaran Discovery Learning siswa lebih aktif dalam memecahkan untuk menemukan, sedangkan guru berperan sebagai pembimbing atau memberikan petunjuk cara memecahkan masalah itu.

Berdasarkan latar belakang di atas, maka dapat dirumuskan suatu masalah sebagai berikut: 1). Bagaimanakah pengaruh metode Discovery Learning terhadap motivasi belajar siswa terhadap mata pelajaran Biologi materi Jamur pada siswa kelas X di SMA Negeri 3 Simpang Hilir Kabupaten Kayong Utara Tahun pelajaran 2015/2016?; 2).bagaimanakah peningkatan prestasi belajar siswa dengan diterapkannya pembelajaran discovery learning terhadap mata pelajaran Biologi materi jamur pada siswa kelas X di SMA Negeri 3 Simpang Hilir Kabupaten Kayong Utara Tahun pelajaran 2015/2016?.

Sesuai dengan permasalahan di atas, penelitian ini bertujuan untuk: 1) mengetahui pengaruh motivasi belajar siswa setelah diterapkan pembelajaran discovery learning pada mata pelajaran Biologi materi Jamur pada siswa kelas $X$ di SMA Negeri 3 Simpang Hilir Kabupaten Kayong Utara Tahun pelajaran 2015/2016; 2) mengetahui peningkatan motivasi serta prestasi belajar siswa setelah diterapkannya pembelajaran discovery learning pada mata pelajaran 
Biologi materi Jamur pada siswa kelas X di SMA Negeri 2 Simpang Hilir Kabupaten Kayong Utara Tahun pelajaran 2015/2016. Penulis mergharapkan dengan hasil penelitian ini dapat bermanfaat bagi: 1). bagi siswa yaitu dapat meningkatkan motivasi belajar serta prestasi siswa pada mata pelajaran Biologi dan mata pelajaran lainnya; 2) bagi guru, dapat memberikan informasi tentang metode pembelajaran yang sesuai dengan materi biologi; 3) bagi sekolah, dapat memberikan masukan untuk sekolah sebagai pedoman untuk mengambil kebijakan di sekolah tersebut; 4) bagi Dinas Pendidikan, dapat digunakan sebagai bahan informasi dan masukan dalam penyusunan program strategis pendidikan yang ada di Kabupaten kayong utara.

Proses dalam pengertian disini merupakan interaksi semua komponen atau unsur yang terdapat dalam belajar mengajar yang satu dengan lainnya saling berhubungan (inter independent) dalam ikatan untuk mencapai tujuan (Usman, 2000: 5).

Belajar diartikan sebagai proses perubahan tingka laku pada diri individu berkat adanya interaksi antara individu dengan lingkungannya. Hal ini sesuai dengan yang diutarakan Burton bahwa seseorang setelah mengalami proses belajar akan mengalami perubahan tingkah laku, baik aspek pengetahuannya, keterampilannya, maupun aspek sikapnya. Misalnya dari tidak bisa menjadi bisa, dari tidak mengerti menjadi mengerti. (dalam Usman, 2000: 5).

Proses belajar mengajar merupakan suatu inti dari proses pendidikan secara keseluruhan dengan guru sebagai pemegangn peran utama. Proses belajar mengajar merupakan suatu proses yang mengandung serangkaian perbuatan guru dan siswa atas dasar hubungan timbal balik yang berlangsung dalam situasi edukatif untuk mencapai tujuan tertentu. Interaksi atau hubungan timbal balik antara guru dan siswa itu merupakan syarat utama bagi berlangsungnya proses belajar mengajar (Usman, 2000: 4).

Dr. J. Richard dan asistennya mencoba self-learning siswa (belajar sendiri) itu, sehingga situasi belajar mengajar berpindah dari situsi teacher learning menjadi situasi student dominated learning. Dengan menggunakan discovery learning, ialah suatu cara mengajar yang melibatkan siswa dalam proses kegiatan mental melalui tukar pendapat, dengan diskusi, seminar, membaca sendiri dan mencoba sendiri, agar anak dapat belajar sendiri.

Motif adalah daya dalam diri seseorang yang mendorongnya untuk melakukan sesuatu, atau keadaan seserang atau organisme yang menyebabkan kesiapan kesiapannya untuk memulai serangkaian tingkah laku atau perbuatan. Sedangkan motivasi adalah suatu proses untuk menggiatkan motif-motif menjadi perbuatan atau tingkah laku untuk memenuhi kebutuhan dan mencapai tujuan, atau keadaan dan kesiapan dalam diri individu yang mendorong tingkah 
lakunya untuk berbuat sesuatu dalam mencapai tujuan tertentu (Usman, 2000: 28).

Sedangkan menurut Djamarah (2002: 114) motivasi adalah suatu pendorong yang mengubah energi dalam diri seseorang kedalam bentuk aktivitas nyata untuk mencapai tujuan tertentu. Dalam proses belajar, motivasi sangat diperlukan sebab seseorang yang tidak mempunyai motivasi dalam belajar tidak akan mungkin melakukan aktivitas belajar. Hal ini sesuai dengan yang diungkapkan oleh Nur (2001: 3) bahwa siswa yang termotivasi dalam belajar sesuatu akan menggunakan proses kognitif yang lebih tinggi dalam mempelajari materi itu, sehingga siswa itu akan meyerap dan mengendapkan mateti itu dengan lebih baik. Jadi motivasi adalah suatu kondisi yang mendorong seseorang untuk berbuat sesuatu dalam mencapai tujuan tertentu.

Menurut jenisnya motivasi dibedakan menjadi dua, yaitu:

a. Motivasi Intrinsik

Jenis motivasi ini timbul sebagai akibat dari dalam individu, apakah karena adanya ajakan, suruhan, atau paksaan dari orang lain sehingga dengan kondisi yang demikian akhirnya ia mau melakukan sesuatu atau belajar (Usman, 2000: 29).

Sedangkan menurut Djamarah (2002: 115), motivasi instrinsik adalah motif-motif yang menjadi aktif atau berfungsinya tidak perlu dirangsang dari luar, karena dalam setiap diri individu sudah ada dorongan untuk melakukan sesuatu.

Menurut Winata (dalam Erriniati, 1994: 105) ada beberapa strategi dalam mengajar untuk membangun motivasi intrinsik. Strategi tersebut adalah sebagai berikut:

1) Mengaitkan tujuan belajar dengan tujuan siswa.

2) Memberikan kebebasan dalam memperluas materi pelajaran sebatas yang pokok.

3) Memberikan banyak waktu ekstra bagi siswa untuk mengerjakan tugas dan memanfaatkan sumber belajar di sekolah.

4) Sesekali memberikan penghargaan pada siswa atas pekerjaannya.

5) Meminta siswa untuk menjelaskan hasil pekerjaannya.

b. Motivasi Ekstrinsik

Jenis motivasi ini timbul sebagai akibat pengaruh dari luar individu, apakah karena adanya ajakan, suruhan, atau paksaan dari orang lain sehingga dengan kondisi yang demikian akhirnya ia mau melakukan sesuatu atau belajar. Misalnya seseorang mau belajar karena ia disuruh oleh orang tuanya agar mendapat peringkat pertama dikelasnya (Usman, 2000: 29). 
Sedangkan menurut Djamarah (2002: 117), motivasi ekstrinsik adalah kebalikan dari motivasi intrinsik. Motivasi ekstrinsik adalah motifmotif yang aktif dan berfungsi karena adanya perangsang dari luar.

Belajar dapat membawa suatu perubahan pada individu yang belajar. Perubahan ini merupakan pengalaman tingkah laku dari yang kurang baik menjadi lebih baik. Pengalaman dalam belajar merupakan pengalaman yang dituju pada hasil yang akan dicapai siswa dalam proses belajar di sekolah. Menurut Poerwodarminto (1991: 768), prestasi belajar adalah hasil yang dicapai (dilakukan, dekerjakan), dalam hal ini prestasi belajar merupakan hasil pekerjaan, hasil penciptaan oleh seseorang yang diperoleh dengan ketelitian kerja serta perjuangan yang membutuhkan pikiran.

Motivasi adalah suatu kondisi yang mendorong seseorang untuk berbuat sesuatu dalam mencapai tujuan tertetntu. Siswa yang termotivasi untuk belajar sesuatu akan menggunakan proses kognitif yang lebih tinggi dalam mempelajari materi itu, sehingga siswa itu akan menyerap dan mengendapkan materi itu dengan lebih baik (Nur, 2001: 3). Sedangkan prestasi belajar adalah hasil yang dicapai oleh siswa dengan melibatkan seluruh potensi yang dimilikinya setelah siswa itu melakukan kegiatan belajar.

Sedangkan metode pembelajaran penemuan (discovery) adalah suatu metode pembelajaran yang memberikan kesempatan dan menuntut siswa terlibat secara aktif di dalam mencapai tujuan pembelajaran dengan memberikan informasi singkat (Siadari, 2001: 7). Pengetahuan yang diperoleh dengan belajar penemuan (discovery) akan bertahan lama, mempunyai efek transfer yang lebih baik dan meningkatkan siswa dan kemampuan berfikir secara bebas. Secara umum belajar penemuan (discovery) ini melatih keterampilan kognitif untuk menemukan dan memecahkan masalah tanpa pertolongan orang lain. Selain itu, belajar penemuan membangkitkan keingintahuan siswa, memberi motivasi untuk bekerja sampai menemukan jawaban (Syafi'udin, 2002: 19).

Dari uraian tersebut di atas dapat disimpulkan bahwa dengan adanya motivasi dalam pembelajaran model penemuan (discovery) tersebut maka hasil-hasil belajar dapat menjadi optimal. Makin tepat motivasi yang diberikan, makin berhasil pula pelajaran itu. Dengan motivasi yang tinggi maka intensitas usaha belajar siswa akan tingi pula. Jadi motivasi dapat senantiasa menentukan intesitas usaha belajar siswa. Hasil ini dapat meningkatkan prestasi belajar siswa. 


\section{METODOLOGI PENELITIAN}

Subyek penelitian adalah siswa kelas X SMA Negeri 3 Simpang Hilir yang terdiri dari 31 siswa dengan mata pelajaran Biologi materi jamur Tahun Pelajaran 2015/2016. Penelitian ini merupakan penelitian tindakan (action research), karena penelitian dilakukan untuk memecahkan masalah pembelajaran di kelas. Penelitian ini juga termasuk penelitian deskriptif, sebab menggambarkan bagaimana suatu teknik pembelajaran diterapkan dan bagaimana hasil yang diinginkan dapat dicapai.

Menurut Sukidin, dkk. (2002:54) ada 4 macam bentuk penelitian tindakan, yaitu: (1) penelitian tindakan guru sebagai peneliti, (2) penelitian tindakan kolaboratif, (3) penelitian tindakan simultan terintegratif, dan (4) penelitian tindakan sosial eksperimental. Sesuai dengan jenis penelitian yang dipilih, yaitu penelitian tindakan, maka penelitian ini menggunakan model penelitian tindakan dari Kemmis dan Taggart (1988:14), yaitu berbentuk spiral dari siklus yang satu ke siklus yang berikutnya. Setiap siklus meliputi planning (rencana), action (tindakan), observation (pengamatan), dan reflection (refleksi). Langkah pada siklus berikutnya adalah perncanaan yang sudah direvisi, tindakan, pengamatan, dan refleksi. Sebelum masuk pada siklus 1 dilakukan tindakan pendahuluan yang berupa identifikasi permasalahan.

Penelitian ini dilaksanakan selama dua siklus/putaran.Observasi dibagi dalam dua putaran, yaitu putaran 1 dan 2 dimana masing putaran dikenai perlakuan yang sama dan membahas satu sub pokok bahasan yang diakhiri dengan tes formatif di akhir masing putaran, serta memperbaiki system pengajarannya. Untuk mengetahui keefektivan suatu metode dalam kegiatan pembelajaran perlu diadakan analisa data. Pada penelitian ini menggunakan teknik analisis deskriptif kualitatif, yaitu suatu metode penelitian yang bersifat menggambarkan kenyataan atau fakta sesuai dengan data yang diperoleh dengan tujuan untuk mengetahui prestasi belajar yang dicapai siswa juga untuk memperoleh respon siswa terhadap kegiatan pembelajaran serta aktivitas siswa selama proses pembelajaran.

Untuk menganalisis tingkat keberhasilan atau persentase keberhasilan siswa setelah proses belajar mengajar setiap putarannya dilakukan dengan cara memberikan evaluasi berupa soal tes tertulis pada setiap akhir putaran. Penentuan rata-rata hasil tes formatif, peneliti melakukan penjumlahan nilai yang diperoleh siswa, yang selanjutnya dibagi dengan jumlah siswa yang ada di kelas tersebut atau dapat dirumuskan:

$$
\bar{X}=\frac{\sum X}{\sum N}
$$

Dengan : $\bar{X} \quad=$ Nilai rata-rata 


$$
\begin{aligned}
\Sigma \mathrm{X} & =\text { Jumlah semua nilai siswa } \\
\Sigma \mathrm{N} & =\text { Jumlah siswa }
\end{aligned}
$$

Ada dua kategori ketuntasan belajar yaitu secara perorangan dan secara klasikal. Berdasarkan petunjuk pelaksanaan belajar mengajar kurikulum 1994 (Depdikbud, 1994), yaitu seorang siswa telah tuntas belajar bila telah mencapai skor $65 \%$ atau nilai 65 , dan kelas disebut tuntas belajar bila di kelas tersebut terdapat $85 \%$ yang telah mencapai daya serap lebih dari atau sama dengan $65 \%$. Untuk menghitung persentase ketuntasan belajar digunakan rumus sebagai berikut:

$$
P=\frac{\sum \text { Siswa.yang.tuntas.belajar }}{\sum \text { Siswa }} \times 100 \%
$$

a. Lembar observasi pengelolaan metode pemberian balikan, untuk menghitung lembar observasi pengelolaan metode pemberian balikan digunakan rumus sebagai berikut:

$$
\bar{X}=\frac{P_{1}+P_{2}}{2}
$$

Dimana: $\mathrm{P}_{1}=$ pengamat 1

$\mathrm{P}_{2}=$ pengamat 2

b. Lembar observasi aktivitas guru dan siswa, untuk menghitung lembar observasi aktivitas guru dan siswa digunakan rumus sebagai berikut.

$$
\begin{aligned}
& \%=\frac{\bar{X}}{\sum X} \times 100 \% \text { dengan } \\
& \bar{X}=\frac{\text { jumlah.hasil.pengamatan }}{\text { jumlah.pengamat }}=\frac{P_{1}+P_{2}}{2} \\
& \text { Dimana: } \begin{aligned}
\% \bar{X} & =\text { Persentase pengamatan } \\
\sum \bar{X} & =\text { Jumlah rata-rata } \\
\mathrm{P}_{1} & =\text { Pengamat } 1 \\
\mathrm{P}_{2} & =\text { Pengamat } 2
\end{aligned}
\end{aligned}
$$

\section{HASIL DAN PEMBAHASAN}

Data penelitian yang diperoleh berupa data observasi berupa pengamatan pengelolaan pembelajaran dan pengamatan aktivitas siswa dan guru pada akhir pembelajaran, dan data tes formatif siswa pada setiap siklus. Data lembar observasi diambil dari dua pengamatan yaitu data pengamatan penglolaan pembelajaran yang digunakan untuk mengetahui pengaruh penerapan metode discovery learning dalam meningkatkan prestasi 
Data tes formatif untuk mengetahui peningkatan prestasi belajar siswa setelah diterapkan pembelajaran discovery learning. Pada siklus pertama meliputi: 1) Tahap Perencanaan; tahap ini peneliti mempersiapkan perangkat pembelajaran yang terdiri dari rencana pelajaran 1, LKS 1 , soal tes formatif 1 , dan alat-alat pengajaran yang mendukung; 2) Tahap Kegiatan dan Pelaksanaan: pelaksanaan kegiatan belajar mengajar untuk siklus I dilaksanakan pada tanggal 23 Agustus 2015 di kelas X yang terdiri dari 31 siswa,dalam hal ini peneliti bertindak sebagai guru. Adapun proses belajar mengajar mengacu pada rencana pelajaran yang telah dipersiapkan. Pengamatan (observasi) dilaksanakan bersamaan dengan pelaksanaan belajar mengajar. Berdasarkan tabel di atas aspek-aspek yang mendapatkan kriteria kurang baik adalah memotivasi siswa, menyampaikan tujuan pembelajaran, pengelolaan waktu. Ketiga aspek yang mendapat penilaian kurang baik di atas, merupakan suatu kelemahan yang terjadi pada siklus I, dan akan dijadikan bahan kajian untuk refleksi dan revisi yang akan dilakukan pada siklus I. Hasil observasi berikutnya adalah aktivitas guru dan siswa dapat dilihat pada Tabel 1 sebagai berikut:

Tabel 1. Aktivitas Guru Dan Siswa Pada Siklus I

\begin{tabular}{|c|l|c|}
\hline No & \multicolumn{1}{|c|}{ Aktivitas Guru yang diamati } & Persentase \\
\hline 1 & Menyampaikan tujuan & 7.67 \\
2 & Memotivasi siswa/merumuskan masalah & 10.00 \\
3 & Mengkaitkan dengan pelajaran berikutnya & 8.33 \\
4 & Menyampaikan materi/langkah-langkah/strategi & 5.00 \\
5 & Menjelaskan materi yang sulit & 18.33 \\
6 & Membimbing dan mengamati siswa dalam menemukan konsep & 20.00 \\
7 & Meminta siswa menyajikan dan mendiskusikan hasil kegiatan & 10.00 \\
8 & Memberikan umpan balik & 15.00 \\
9 & Membimbing siswa merangkum pelajaran & 6.67 \\
\hline No & \multicolumn{1}{|c|}{ Aktivitas Siswa yang diamati } & Persentase \\
\hline 1 & Mendengarkan/memperhatikan penjelasan guru & 20,63 \\
2 & Membaca buku siswa & 12.29 \\
3 & Bekerja dengan sesama anggota kelompok & 18.75 \\
4 & Diskusi antar siswa/antara siswa dengan guru & 14.38 \\
5 & Menyajikan hasil pembelajaran & 3.96 \\
6 & Mengajukan/menanggapi pertanyaan/ide & 6.25 \\
7 & Menulis yang relevan dengan KBM & 8.75 \\
8 & Merangkum pembelajaran & 6.88 \\
9 & Mengerjakan tes evaluasi & 8.13 \\
\hline
\end{tabular}


Berdasarkan tabel di atas tampak bahwa aktivitas guru yang paling dominan pada siklus I adalah membimbing dan mengamati siswa dalam menemukan konsep yaitu masing-masing dan menjelaskan materi yang sulit 20,00 dan 18,33\%. Aktivitas lain yang persentasenya cukup besar adalah memberi umpan balik yaitu $15,00 \%$. Sedangkan aktivitas siswa yang paling dominan adalah mengerjakan/memperhatikan penjelasan guru yaitu 20,63\% . Aktivitas lain yang persentasenya cukup besar adalah bekerja dengan sesama anggota kelompok, diskusi antar siswa/antara siswa dengan guru, dan membaca buku yaitu masing-masing 18,13\%, 18,37 dan 1438\%.

Pada siklus I, secara garis besar kegiatan belajar mengajar dengan metode discovery learning sudah dilaksanakan dengan baik, walaupun peran guru masih cukup dominan untuk memberikan penjelasan dan arahan karena model tersebut masih dirasakan baru oleh siswa. Hasil rekapitulasi tes formatif siswa antar kelas dapat dilihat pada Tabel 2 sebagai berikut:

Tabel 2. Rekapitulasi Hasil Tes Formatif Siklus I

\begin{tabular}{|c|l|c|}
\hline No & \multicolumn{1}{|c|}{ Uraian } & Nilai Tes Siklus I \\
\hline 1 & Nilai rata-rata tes formatif & 51,61 \\
2 & Jumlah siswa yang tuntas belajar & 7 \\
3 & Persentase ketuntasan belajar & 22,58 \\
\hline
\end{tabular}

Pada Siklus II meliputi beberapa tahapan 1) tahap perencanaan: pada tahap ini peneliti mempersiapkan perangkat pembelajaran yang terdiri dari rencana pelajaran 2, LKS 2, soal tes formatif II, dan alat-alat pengajaran yang mendukung. 2) tahap kegiatan dan pelaksanaan: pelaksanaan kegiatan belajar mengajar untuk siklus II dilaksanakan pada tanggal 7 September 2015 di kelas $\mathrm{X}$ yang terdiri dari 31 siswa. Dalam hal ini peneliti bertindak sebagai guru. Adapun proses belajar mengajar mengacu pada rencana pelajaran dengan memperhatikan revisi pada siklus I, sehingga kesalahan atau kekurangan pada siklus I tidak terulang lagi pada siklus II. Pengamatan (observasi) di laksanakan bersamaan dengan pelaksanaan belajar mengajar.

Dengan penyempurnaan aspek-aspek di atas dalam penerapan metode pembelajaran penemuan (discovery) diharapkan siswa dapat menyimpulkan apa yang telah mereka pelajari dan mengemukakan pendapatnya sehingga mereka akan lebih memahami tentang apa yang telah mereka lakukan dapat disajikan dalam Tabel 3. sebagai berikut: 


\section{Tabel 3. Aktivitas Guru Dan Siswa Pada Siklus II}

\begin{tabular}{|c|l|c|}
\hline No & \multicolumn{1}{|c|}{ Aktivitas Guru yang diamati } & Persentase \\
\hline 1 & Menyampaikan tujuan & 6.67 \\
2 & Memotivasi siswa/merumuskan masalah & 6.67 \\
3 & Mengkaitkan dengan pelajaran berikutnya & 6.67 \\
4 & Menyampaikan materi/langkah-langkah/strategi & 11.67 \\
5 & Menjelaskan materi yang sulit & 11.67 \\
6 & Membimbing dan mengamati siswa dalam menentukan konsep & 25.00 \\
7 & Meminta siswa menyajikan dan mendiskusikan hasil kegiatan & 8.33 \\
8 & Memberikan umpan balik & 16.67 \\
9 & Membimbing siswa merangkum pelajaran & 6.67 \\
\hline No & \multicolumn{1}{|c|}{ Aktivitas Siswa yang diamati } & Persentase \\
\hline 1 & Mendengarkan/memperhatikan penjelasan guru & 17.90 \\
2 & Membaca buku siswa & 14.15 \\
3 & Bekerja dengan sesama anggota kelompok & 19.78 \\
4 & Diskusi antar siswa/antara siswa dengan guru & 13.95 \\
5 & Menyajikan hasil pembelajaran & 5.00 \\
6 & Mengajukan/menanggapi pertanyaan/ide & 5.63 \\
7 & Menulis yang relevan dengan KBM & 7.50 \\
8 & Merangkum pembelajaran & 6,67 \\
9 & Mengerjakan tes evaluasi/latihan & 9.38 \\
\hline
\end{tabular}

Pada akhir proses belajar mengajar siswa diberi tes formatif II dengan tujuan untuk mengetahui tingkat keberhasilan siswa selama proses belajar mengajar yang telah dilakukan. Instrument yang digunakan adalah tes formatif II.

Berdasarkan tabel di atas tampak bahwa aktivitas guru yang paling dominan pada siklus II adalah membimbing dan mengamati siswa dalam menentukan konsep yaitu $25.00 \%$, memberikan umpan balik yaitu 16,67\%, kemudian menyampaikan langkah-langkah strategis dan memberi umpan balik yaitu masing-masing 11,67\%. Sedangkan, untuk aktivitas siswa yang paling dominan pada siklus II adalah bekerja dengan sesama anggota kelompok, mendengarkan penjelasan guru, membaca buku, dan diskusi antar siswa/antara siswa dengan guru yaitu $19.78 \%, 17.90 \%, 14.15 \%$ dan $13.95 \%$.

Untuk hasil rekapitulasi tes formatif siswa dapat dilihat pada Tabel 4. sebagai berikut; 
Tabel 4. Rekapitulasi Hasil Tes Siklus II

\begin{tabular}{|c|l|c|}
\hline No & \multicolumn{1}{|c|}{ Uraian } & Nilai Tes Siklus II \\
\hline 1 & Nilai rata-rata tes formatif & 71,13 \\
2 & Jumlah siswa yang tuntas belajar & 22 \\
3 & Persentase ketuntasan belajar & 70,97 \\
\hline
\end{tabular}

Dari tabel di atas diperoleh nilai rata-rata prestasi belajar siswa adalah 71,13 dengan rata-rata71,13. Adanya peningkatan hasil belajar siswa ini karena setelah guru menginformasikan bahwa setiap akhir pelajaran akan selalu diadakan tes sehingga pada pertemuan berikutnya siswa lebih termotivasi untuk belajar. Selain itu siswa juga sudah mulai mengerti apa yang dimaksudkan dan diinginkan guru dengan menerapkan metode discovery learning.

\section{KESIMPULAN DAN SARAN}

Berdasarkan hasil penelitian dan pembahasan yang telah diuraikan, maka dapat disimpulkan sebagai berikut:

1. Penerapan metode Discovery Learning untuk meningkatkan motivasi belajar siswa kelas X mata pelajaran Biologi materi Jamur di SMA Negeri 3 Simpang Hilir Kabupaten Kayong Utara Tahun Pelajaran 2015/2016 siswa tertarik dan antusias dalam mengikuti pelajaran. Hambatan yang terjadi pada pembentukan kelompok dan siswa disuruh melakukan presentasi, namun hal ini dapat diatasi dengan memberikan bimbingan dan motivasi yang lebih intensif.

2. Pembelajaran dengan penemuan (discovery) memiliki dampak positif dalam meningkatkan prestasi belajar siswa yang ditandai dengan peningkatan ketuntasan belajar siswa dalam setiap siklus, yaitu siklus I $(22,58 \%)$, dan siklus II (70,97\%), sehingga dapat disimpulkan aktivitas siswa selama pembelajaran dengan metode discovery learning dapat meningkatkan aktivitas siswa dengan kriteria siswa aktif.

3. Penerapan metode pembelajaran discovery learning mempunyai pengaruh positif, yaitu dapat meningkatkan motivasi belajar siswa yang ditunjukan dengan hasil wawancara dengan sebagian siswa, rata-rata jawaban siswa menyatakan bahwa siswa tertarik dan berminat dengan metode pembelajaran penemuan (discovery) sehingga mereka menjadi termotivasi untuk belajar. 


\section{DAFTAR RUJUKAN}

Arikunto, Suharsimi. 2001. Dasar-dasar Evaluasi Pendidikan. Jakarta: Bumi Aksara.

Arikunto, Suharsimi. 2002. Prosedur Penelitian Suatu Pendekatan Praktek. Jakarta:Rineksa Cipta.

Departemen Pendidiakan dan Kebudayaan, 1994. Petunjuk Pelaksanaan Proses Belajar Mengajar. Jakarta. Balai Pustaka.

Djamarah, Syaiful Bahri. 2002. Strategi Belajar Mengajar. Jakarta: Rineksa Cipta.

Djamarah. Syaiful Bahri. 2002. Psikologi Belajar. Jakarta:Rineksa Cipta.

Kemmis, S. dan Mc. Taggart, R. 1988. The Action Research Planner. Victoria Dearcin University Press.

Margono. 1997. Metodologi Penelitian Pendidikan. Jakarta: Rineksa Cipta.

Ngalim, Purwanto M. 1990. Psikologi Pendidikan. Bandung: Remaja Rosdakarya.

Nur, Moh. 2001. Pemotivasian Siswa untuk Belajar. Surabaya. University Press. Universitas Negeri Surabaya.

Poerwodarminto. 1991. Kamus Umum Bahasa Indonesia. Jakarta:Bina Ilmu.

Sukidin, dkk. 2002. Manajemen Penelitian Tindakan Kelas. Surabaya: Insan Cendekia.

Suryosubroto. 1997. Proses Belajar Mengajar di Sekolah. Jakarta:PT. Rineksa Cipta.

Syafi'udin. 2002. Penerapan Pendekatan Konstruktivis dengan menggunakan Metode Penemuan untuk Meningkatkan Prestasi Belajar Siswa Kelas I MTsN Denanyar. Skripsi yang tidak dipublikasikan Universitas Negeri Surabaya.

Syah, Muhibbin. 1995. Psikologi Pendidikan, Suatu Pendekatan Baru. Bandung: Remaja Rosdakarya.

Usman, Uzer. 2000. Menjadi Guru Profesional. Bandung:PT. Remaja Rosdakarya. 